\title{
Social media data as a user perception tool: Evaluation of user experiences in Sultanahmet Area
}

\author{
Kullanıcı algısı aracı olarak sosyal medya \\ verileri: Sultanahmet Bölgesi'ndeki kullanıcı \\ deneyimlerinin değerlendirilmesi
}

Gönderim Tarihi / Received : 17.01.2021

Kabul Tarihi / Accepted : : 16.04.2021

Doi: https://doi.org/10.31795/baunsobed.854753

\section{Ezgi GÜLER TOZLUOĞLU' Çağlar TOZLUOĞLU² Dilcan GÜLER ${ }^{3}$ Mehmet Emre GÜLER**a}

\begin{abstract}
Social media and new communication technologies have been developing rapidly in recent years and contribute to urban studies. The massive data provided by mobile devices and web services remark a new information source that can be functional in city-specific decision-making. With these features, social networks can show urban life's situation about each user's unique social, economic, and political aspects. In this context, data obtained from new media and social networks in planning the cities' touristic areas will contribute to regional and local tourism planning. This study focuses on the analysis and evaluation of the data set obtained from the Flickr and Foursquare applications, which are location-based social networks, and their contribution to urban design and tourism studies. Each social media application was evaluated within itself and a holistic evaluation was made in the city square with the data obtained between the years of 2004-2018. In the research area designated as Sultanahmet Square, the experiences and perceptions of individuals using the specified web applications were examined.
\end{abstract}

Keywords: Tourism, Urban square, Social media, Data analysis, Sultanahmet square.

\footnotetext{
"Sorumlu Yazar / Corresponding Author

${ }^{1}$ Ph.D. Student, Istanbul Technical University, Faculty of Architecture, Department of Urban and Regional Planning, gulerezg@itu.edu.tr, https://orcid.org/0000-0002-4765-6782

${ }^{2}$ Ph.D. Student, Chalmers University of Technology, Department of Space, Earth and Environment, Physical Resource Theory, caglar.tozluoglu@chalmers.se, https://orcid.org/0000-0001-7686-7696

${ }^{3}$ Software Support Specialist, Izmir Kâtip Celebi University, Department of Information Technology, dilcan.guler@ikcu.edu.tr, https://orcid.org/0000-0002-8531-6842

${ }^{4}$ Prof., Izmir Kâtip Çelebi University, Faculty of Tourism, Department of Tourism Management, memre.guler@ikcu.edu.tr, https://orcid.org/0000-0002-8689-9859
} 
ÖZ: Sosyal medya ve yeni iletişim teknolojileri son yıllarda hızla gelişmekte ve kent çalışmalarına katkı sağlamaktadır. Mobil cihazlar ve web hizmetleri tarafından sağlanan büyük veriler, kente yönelik karar verme mekanizmalarında işlevsel olabilecek yeni bir bilgi kaynağına işaret etmektedir. Bu özellikleri ile sosyal ağlar, kent ve kentteki her kullanıc1nın özgün sosyal, ekonomik ve politik yönleri hakkındaki durumunu göstermektedir. Bu kapsamda şehirlerin turistik alanlarının planlanmasında yeni medya ve sosyal ağlardan elde edilen veriler bölgesel ve yerel turizm planlamasına katkı sağlayacak özelliktedir. Bu çalışma, konum temelli sosyal ağlardan biri olan Flickr ve Foursquare uygulamasından elde edilen veri setinin analiz süreci, değerlendirilmesi ve kent ve turizm çalışmalarına katkısına odaklanmaktadır. 2004-2018 yılları arasında elde edilen veriler ile her sosyal medya uygulaması kendi içinde değerlendirilerek kent meydanında bütüncül bir değerlendirme yapılmaktadır. Sultanahmet Meydanı özelinde, belirtilen web uygulamalarını kullanan bireylerin deneyimleri ve paylaşımları üzerinden kullanıcı algıları incelenmektedir.

Anahtar Kelimeler: Turizm, Kent meydanı, Sosyal medya, Veri analizi, Sultanahmet meydani. 


\section{GENIŞLETILLMIŞ ÖZET}

\section{Literatür taraması}

Şehirler genellikle kültürel veya doğal yerler gibi birçok turistik cazibe merkezi içermektedir. Bu cazibe merkezleri ise şehrin değişik bölgelerinde bulunabilmektedir. Gerçekleştirilen şehir turları, farklı konumlar, zaman, mesafe, maliyet gibi çeşitli unsurlar dengelenerek düzenlenmektedir. Bu nedenle, seyahat turları, şehir ölçeğinde farklı yerler arasındaki ilişkileri daha iyi ortaya koyabilmektedir. Bu noktada Shao vd. (2017), sosyal medya verilerinden mekânsal-zamansal turist davranışlarını anlamak için bir model geliştirmişler ve bu model daha sonra şehrin turizm bölgelerini çıkarmak ve analiz etmek için kullanılmıştır. Son yıllarda dijital veriler kullanılarak şehir yapısı ve turist davranışları üzerine çeşitli çalışmalar yapılmıştır. Asakura ve Iryo (2007), turist davranış özelliklerini keşfetmek için mobil konumlandırma verilerine küme analizi uygularken, Zhai vd. (2015), sosyal medya verilerini kullanarak şehirlerdeki restoranların popülerliğini ortaya çıkarmaya çalışmıştır. Cranshaw vd. (2012) bir şehrin yapısını şehir sakinlerinin Facebook ve Twitter verilerine dayanarak incelemek için bir kümeleme modeli ve araştırma metodolojisi geliştirmiştir. Hollenstein ve Purves (2015), ABD'deki şehirlerin merkezî konumlarının, kullanıcılar tarafından oluşturulan Flickr verilerini kullanarak, nasıl etiketlendiğini ve bu konumların sınırlarını araştırırken Yin vd. (2011), fark11 şehirlerdeki Flickr kullanıcılarının tur rotalarını, coğrafi etiketlerini ve saat dilimlerini takip ederek şehirdeki turistik rotaları ortaya çıkarmaya çalışmıştır. Frias-Martinez vd. (2012), coğrafi olarak konumlandırılmış tweetleri, şehir planlama uygulamaları için tamamlayıcı bir bilgi kaynağı olarak kullanmış ve coğrafi olarak konumlandırılmış tweetlerin kentsel çevreleri karakterize etmek için güçlü ve dinamik bir veri kaynağı olduğu sonucuna varmıştır. Chua vd. (2016), Güney İtalya'daki bölgesel bir turistik cazibe merkezi olan Cilento'daki turist akışlarının mekânsal, zamansal ve demografik özelliklerini belirlemek için Twitter'daki coğrafi etiketli sosyal medya verilerini analiz etmiştir.

Foursquare gibi lokasyon bazlı sosyal medya verileri tüm kullanıcıları kapsamadığ için kentsel araştırmalarda kullanımı tartışılan konular arasındadır (Taras vd., 2016). Genel olarak, web hizmetleri tarafından sağlanan bilgiler, özel bir şirkete ait verilerin bir parçasıdır. Ancak kentsel analizde sosyal ağların rolü üzerine yapılan çalışmalar kısmi kabullere dayanmaktadır. (Bawa-Cavia, 2011; Cerrone, 2015). Bu makalede, Foursquare ve Flickr olmak üzere iki farklı platformdan toplanan sosyal medya verileri mekânsal ve zamansal olarak analiz edilmektedir. Bu veriler, şehir meydanındaki ziyaret kalıplarını tahmin etmek için kullanılabilirlikleri açısından değerlendirilmiştir. Sonuç olarak kullanıcının mekânla ilgili verileri ile görsel, anlamsal ve uzamsal çıkarımlar 
yapılmış ve kent meydanının kullanımı ve yeni teknoloji ile kent turizmi arasındaki ilişki tartışılmıştır.

\section{Yöntem}

Çalışmada, seçilen vaka alanında Foursquare API ve Flickr'dan kullanıcı değerlendirmelerinin hem sözlü hem de görsel olarak analizi gerçekleştirilmektedir. Vaka alanının seçildiği il olan İstanbul, yüksek kullanıcı sayısı ve zengin turizm altyapısı özelliği dolayısıyla seçilmiştir. İstanbul'da seçilen örnek alan ise en ünlü turistik meydanlardan biri olan Sultanahmet Meydanı'dır. Çalışma, kent meydanına özgü bir yöntem önerisi geliştirse de, geliştirilen bu yöntem önerisi diğer turistik kamusal alanlarda da kullanılabilir niteliktedir. $\mathrm{Bu}$ bağlamda, önerilen yöntem, turistik alanlarda kullanıcı önceliklerini belirlemek ve bu bilgileri turizm alanı tasarımına entegre etmek için de kullanılabilir.

\section{Bulgular ve tartışma}

Flickr'dan temin edilen kullanıcıların paylaştığ1 6329 görsel ve etiketleri incelenmiş ve sonuçta paylaşılan fotoğrafların çoğunun mimari unsurlar içeren fotoğraflar olduğu ortaya konmuştur. Paylaşılan fotoğrafların \% 84'ü meydanın çevresindeki tarihi yapıların fotoğraflarıdır. Özellikle kullanıcılar hem iç hem de cephe olmak üzere tarihi cami fotoğraflarını paylaşmışlardır. Paylaşılan fotoğrafların Sultanahmet Meydanı'ndaki meydanın tarihi ve mimari kimliğini yansıttığı görülmüştür. Fotoğrafların geri kalanı ise meydanda bulunan çeşmeler, ağaçlar, 1şıklar gibi peyzaj unsurları olarak nitelendirilmiştir. Kent meydanlarında bu tür peyzaj unsurlarının kentsel tasarım ve turizm çekiciliği açısından olumlu tasarımlar olduğu sonucuna varmak mümkündür.

Araştırmada incelenen kullanım yoğunluğu analizleri, Foursquare uygulamasını kullanan kişilerin verilerini içermektedir. Bu nedenle uygulamanın kullanıcısı olmayan kişiler temsil edilememektedir. Ağustos 2011 - Ağustos 2018 tarihleri arasında İstanbul kent meydanlarında toplam 18.459.291 check-in bildirimi tespit edilmiştir. Bu bildirimlerin 860.313'ü Sultanahmet Meydanı'nda bulunmaktadır. Foursquare uygulamasından alınan veriler, şehir meydanları için yorumları ve tarihleri içermektedir. Sultanahmet Meydanı hakkında toplam 1000 yorum alınmıştır. Sosyal medya verilerinden elde edilen kullanıcı deneyimine dayalı yorumlar sayesinde yıl içerisinde meydanlardaki kullanıcıların yoğunluğuna ulaşılmıştır. Böylece hem mekânsal hem de zamansal olarak değerlendirme yapmak mümkün olmuştur. Buna göre meydanın kullanıcıları yaz aylarında meydanla ilgili daha çok yorumda bulunmuştur. API ile kentsel meydanların kullanıcı yorumları elde edildikten sonra analizler iki farklı aşamada gerçekleştirilmiştir. Öncelikle kullanıcı yorumları metin analizi yön- 
temleri ile incelenmiş ve sonrasında şehir meydanında en çok kullanılan kelimeler belirlenmiştir. Ayrıntılı metin analizine göre Sultanahmet»te «güzel», «meydan», «tarih», «sakin», «Sultanahmet», «ağaç», «harika» ve «Ramazan» kelimelerinin daha çok kullanıldığı görülmektedir.

Sultanahmet Meydanı'nın tarihi yapısı, alışveriş yerlerinin fazla olması, meydanda ağaçların bulunması olumlu özellikler olarak nitelendirilmektedir. Daha çok yaz aylarında yorum yapılan meydanın, yaz aylarında ağaçların ve rüzgârın ziyaretçilere rahatlık hissi verdiği anlaşılmaktadır. Yeni meydan düzenlemesinden dolayı beton zeminin artış hızı olumsuz olarak değerlendirilmektedir.

\section{Sonuç ve öneriler}

Destinasyonlarla ilgili lokasyon bazlı sosyal medya ağları ile toplanan veriler turizm çalışmalarına ve kentsel tasarıma büyük katkı yapmaktadır. Bu veriler destinasyonun popüler alanlarını, özelliklerini ve sorunlarını belirlemeyi kolaylaştırabilir. Kent meydanları söz konusu olduğunda bu durum, kullanıcıların olumsuz olarak algıladığı faktörlerin kısa sürede tespit edilmesini ve tasarım probleminin ortaya konulmasını sağlar. Öte yandan akıllı şehir sistemleri ile sosyal medya verileri gibi kullanıcı tabanlı verilerin entegrasyonu, şehrin kullanıcı deneyimlerine dayalı olarak geliştirilmesi için çok önemlidir.

Sosyal medya verileri, turizm alanındaki sorunların ve kullanıcı tercihlerinin hızlı bir şekilde belirlenmesine yönelik yapılan çalışmalara katkı sağlamaktadır. Ayrıca turistlerin algısı, alan kullanımı ve bölgenin imajı hakkında önemli bilgiler elde edilebilmektedir.

$\mathrm{Bu}$ çalışmada, İstanbul'un tarihi yarımadasının önemli bir ziyaret yeri olan Sultanahmet Bölgesi'nde ziyaretçilerin görüşlerini ortaya çıkarmak için sosyal medya verileri kullanılmıştır. Ziyaretçiler, Foursquare ve Flickr uygulamalarını kullanarak seyahatleri hakkında görsel ve yazılı veriler üretmiş ve bu çalışmada, bu verilerin analizi için bir metodoloji önerisi sunulmuştur. Önerilen metodoloji, kent meydanlarının sosyal medyada aldığı yorumların bir veri olarak kent araştırmalarına katkısını incelemektedir. Bu çalışma, bu verilerin şehir ve turizm ilişkisinin geliştirilmesine katkıda bulunup bulunmadığını test etmeyi amaçlamaktadır. Buna göre sosyal medya verileri, meydanların bulunduğu çevrenin karakterini yansıtmakta; turistik meydanın kullanımında tarihi ve mimari karakterin, arazi kullanım şeklinin ve meydan içerisinde yaya hareketinin kolaylığının önemli faktörler olduğu sonucuna vurgulamaktadır. Bu çalışma, kentsel tasarım, turizm ve kentsel algı arasındaki araştırma boşluğunu doldurmada bir öneri sunmaktadır. 


\section{Introduction}

The inclusion of user-oriented approaches and new technologies providing information about a city increases urban planning and tourism. (Lazer et al., 2009; Borrego-Jaraba et al., 2011; Gretzel, 2011; Egger, 2013; Offenhuber and Ratti, 2014). In particular, social media data that allow location sharing has information that can be useful not only in data analysis but also in the planning, design, and decision-making processes by linking individuals' activities to the urban area (Ciuccarelli, 2014).

The use of urban areas, the meanings of space and user experiences have changed due to digitalization evolution in the last century. Big data, emerging from digitalized cities, provide us with significant opportunities to evaluate people's experience with the city. People produce much data during the day through applications in smartphones, tablets, and similar tools that are commonly used. Users contribute to the information production process by sharing their photos, location, and making personal comments about places. This data reveal many virtual spaces beginning to emerge as research objects (Batty, 1990). These virtual spaces and digital information networks are described as 'the city turning into a constellation of computers'. (Batty, 1991). Accordingly, the output arising from social networks can be transformed into valuable inputs from different disciplines. It can be associated with other urban and social factors as multi-layered due to the city's structure.

A significant social media source is obtained through social media services that include data on people's mobility and comments with the increasing number of mobile devices (Numni, 2017). According to the study conducted in 2020,60\% of world's populations are active social media users and social networking usage in Turkey has gained considerable popularity as in the world. (Wearesocial, 2020). Social media is essential for communication, but for planning and design to collect and analyze the users' data are also important. Having users who have high interaction with technology provides essential contributions to urban studies. It is crucial to be aware of this information network and to include it in smart city systems in planning and decisionmaking processes. These innovations contribute to the city's planning and design, from sustainable tourism planning to sustainable economic growth.

Different methods have been developed with the studies carried out in different disciplines to collect and evaluate social media data correctly. Many studies have utilized this data as a source of information for urban planning studies, tourism, and destination management (Elwood, 2012; Girardin et al., 2009; Heikinheimo et al., 2017; Senefonte et al., 2020; Shem-Tov and Bekhor, 2020). For example, Foursquare location check-in density was used to identify 
prominent urban activity areas in Madrid and Barcelona (Nolulas, 2011). Other Foursquare and Flickr datasets are analyzed to examine users' user movement patterns and activities (Silva, 2013).

The perception and satisfaction of the public/ touristic areas and problematic areas are determined by location-based social media data based on the user comments and photo sharing. It is important to integrate location-based user data into planning and tourism studies. The main objective of this research is to indicate users' perception of the tourism area using social media data analysis. It can also be used to determine the effects of design parameters and design priorities in tourism areas with the proposed methodology.

\section{Literature review}

The most important feature of the information age is the practical analysis of the big data obtained. In this way, big data is vital for every industry and has found a wide range of uses (Hashem et al., 2015). Big data is produced in very different ways from many different channels with the developing technology. Li et al. (2018) examine big data production in three groups: (1) data produced by users (user-generated data) over the Internet and generally through social media platforms; (2) The data obtained by examining the Internet of Things, the movements of tourists together with the technologies and the seasonal and environmental conditions; (3) The transaction data resulting from transactions such as web searches, reservations and purchasing activities related to tourism products.

Big data analysis is one of the most powerful tools that affect the tourism industry. It also plays an essential role in strategizing tourism businesses and non-governmental organizations (Song and Liu, 2017). Advances in technology have radically changed how information is produced and consumed by all actors involved in tourism. With the developing technologies, tourists can access different information sources, create their content, and share their views and experiences. Tourism content shared through social media has become a useful information source affecting tourism (Alaei et al., 2019). While using mobile technologies, travelers create large amounts of data by leaving different digital traces about any travel stage (Hendrik and Perdana, 2014; Cools et al., 2021). Big data used in tourism has some advantages such as reliability, continuous information flow, and real-time data compared to traditional methods. Every individual trying to plan a trip uses the internet to buy tickets, book accommodation, or explore tourist destinations. In summary, each actor in the tourism industry has the starting point as analyzing the social media data or big data (Song and Liu, 2017). 
Salas-Olmedo et al. (2018) analyze the digital footprint of tourists through Big Data. As the data source of the analysis, Panoramio, Foursquare, and Twitter, which share the different tourism activities in the cities, were used. Wood et al. (2013) investigate whether the "big data" source can be used to determine the visit rates in their works. They use the location tags of the photos on Flickr to estimate the visit rates and the information from the photographers' Flickr profiles to obtain travelers' origins. Thus, it has been tried to understand which elements of the destination attract people. In their study, del Vecchio et al. (2018) aimed to show how important social big data obtained from tourists improve the value creation process for the Smart Tourism Destination. Thus, they tried to reveal the regional tourism experience and value creation models produced by Big Data in tourism. Chareyron et al. (2014) focus on a digital tourist research area based on big data to be obtained through the study of social networks.

On the other hand, Fuchs et al. (2014) propose a Destination Management Information System in Sweden's mountain tourism region. This proposed system aims to increase the skills of creating and applying the tourism destination information as a Business Intelligence Model based on real data. Irudeen and Samaraweera (2013) try to provide a conceptual and technical solution for an application integrated with Big Data indicators and online transaction and processing systems. In that study for the Travel and Tourism industry in Sri Lanka, an analysis of the Visiting Index, Wealth Index, Health Index, and Lifestyle Index data is presented. In this way, they try to design an open architecture that can track tourists' behavior and turn them into information.

As a destination, cities often contain lots of tourist attractions, such as cultural or natural landmarks. These landmarks are scattered across the city areas. The tours are organized by users in a city using the data as the distance between different locations and time and cost constraints, differences, and similarities between locations as other factors. Therefore, users' travel tours can better understand the relationships between different landmarks on a city scale. At this point, Shao et al. (2017) developed a model to figure out the spatialtemporal tourist behaviors from social media data, and this information was then used to extract and analyze the city's tourism regions. Various studies have been conducted on city structure and tourist behaviors using digital data in recent years. Asakura and Iryo (2007) applied cluster analysis to Mobile positioning data to discover tourist behavior features, while Zhai et al. (2015) tried to reveal the popularity of restaurants in cities using social media data. Cranshaw et al. (2012) developed a clustering model and research methodology to examine a city's structure and composition based on city residents' Facebook 
and Twitter data. Hollenstein and Purves (2015) investigate the boundaries of these locations by investigating how central locations of cities across the USA are labeled using user-generated Flickr data, while Yin et al. (2011) tried to reveal touristic routes in the city area by following tour routes, geotags and time zones of busy Flickr users in different cities. Frias-Martinez et al. (2012) concluded that geographically positioned tweets are a powerful and dynamic data source for characterizing urban environments, evaluating the use of geolocated tweets as a complementary source of information for city planning practices. Chua et al. (2016) analyzed geotagged social media data on Twitter to determine the spatial, temporal, and demographic characteristics of tourist streams in Cilento, a regional tourist attraction in Southern Italy.

Since location-based social media data such as Foursquare do not cover all users, its use in urban studies is among the discussed topics (Taras et al., 2016). In general, the information provided by web services is part of the data owned by a private company. However, studies on social networks' role in urban analysis are based on partial acceptance. (Bawa-Cavia, 2011; Cerrone, 2015).

In this article, social media data collected from two different platforms, Foursquare and Flickr, are analyzed spatially and temporally. These data are evaluated for their availability to estimate the patterns of visits in the city square. As a result, visual, semantic, and spatial reading are made with the user's data about the space. The use of urban square and the relationship between new technology and urban tourism is discussed.

\section{Methodology}

The method of the study consists of two stages: the verbal and visual analyses of user evaluations from Foursquare API and Flickr in the selected case area. Due to the high number of users and rich touristic background, Istanbul was chosen as the province where the case area was selected. Sultanahmet Square, which is one of the most famous touristic squares, was selected as a case area. Although the study develops a method proposal specific to the city square, this method proposal is developed and can be used in other touristic public areas. In this respect, the proposed method can also be used to determine user priorities in tourism areas and to integrate this information into tourism area design.

\section{Data set}

The base of the methodology is to check whether the data generated by users of Foursquare and Flickr can represent the usage and user relationships of the urban square. Foursquare and Flickr applications were chosen in this study because they can provide rich data based on location within the city. Those 
applications are preferred to be used in the research because each has a low cost, is obtained quickly, and easily accessible to the data since they provide the users with producing location-based service. A total of 1000 reviews from Foursquare and 6329 photos from Flickr were gained about Sultanahmet Square. The dataset flowchart shows the methodology used in this paper (Figure 1).

\section{Figure 1: Dataset diagram}

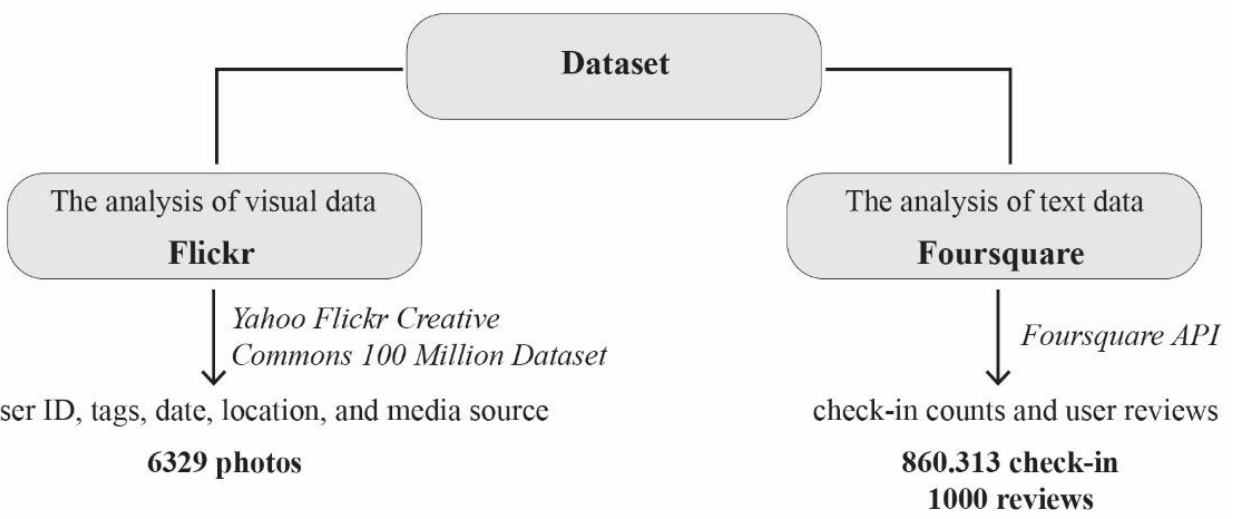

The Foursquare application, which collects visual, text, and number of people data on location information, and Flickr application, which allows location marking and serves as a visual sharing application on the basis, are selected for city square analysis.

In this study, the analysis of visual data was taken from Yahoo Flickr Creative Commons 100 Million Dataset (YFCC100M) website. This data set contains a total of 100 million media objects, all of which are licensed under Creative Commons, installed between 2004 and 2014 (Thomee et al.,2015). Each object in the data set contains a user ID, tags, date, location, and media source. Studies conducted with this method have been used in urban scale to determine whether the users are local or tourist (García-Palomares et al., 2015,).

Secondly, the number of location notifications in the square and user data is obtained using the programming language Python, Foursquare Application Programming Interface (API) to evaluate the intensity of the square's use. Also, check-in counts and user comments of the city square are obtained through the Foursquare API. User reviews are examined with detailed text analyzes, and their suitability with the characteristic features of urban squares was evaluated. In this study, we try to make inferences about the square and user perception's identity by analyzing the areas shared by the users around the city square. 


\section{Case Area}

City squares are public open spaces that add identity to the city both physically and socially. In this context, it is vital to select the case areas from the city squares in terms of open space and user relations evaluation. Sultanahmet Square has been determined as the touristic square with the highest user density in Istanbul's historical urban area (Figure 2).

Sultanahmet Square, one of the oldest squares of İstanbul, has a historic structure and has been home to baths, shrines, cultural, and social centers since the settlement began and it carries the Hellenistic traces, Roman, Byzantine, and Ottoman periods. With this feature, Sultanahmet Square, which has been on the UNESCO World Heritage List since 1985, is still one of the most visited tourist centers in İstanbul with its many historical monuments around it.

Figure 2: Left: Istanbul map; Middle: Historical peninsula map; Right: Sultanahmet Square
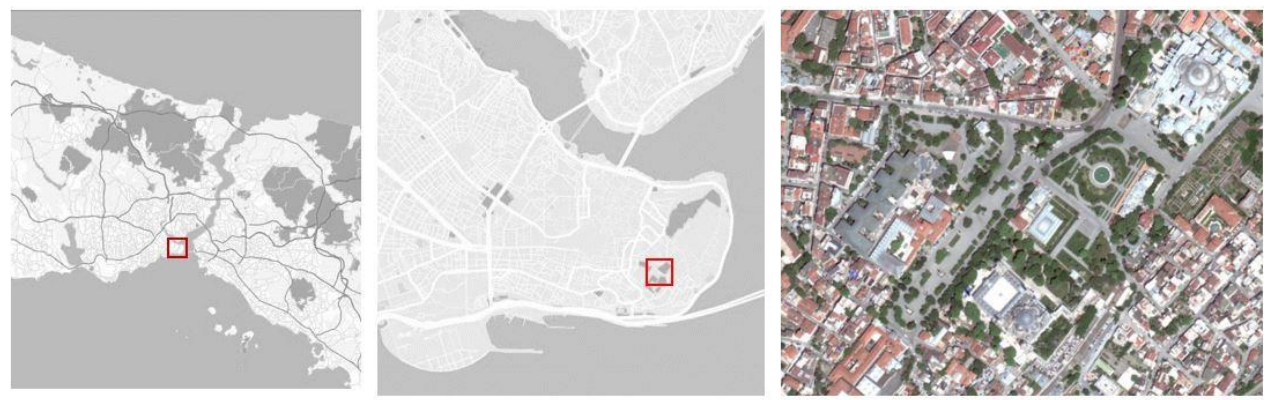

\section{Findings}

\section{Identity elements of urban square}

The 6329 images and their tags shared by users obtained from Flickr were examined, and as a result, it was understood that most of the photos shared were the photographs with architectural elements. $84 \%$ of the shared photos are the photographs of historical buildings around the square. Especially users shared the historical mosque photographs, both indoor and facade. It is seen that the shared photos reflect the historical and architectural identity of the square in Sultanahmet Square. The rest of the photographs, on the other hand, are observed as landscape elements such as fountains, memorial trees, and lights in the square. It is possible to deduce that such landscape elements are positive designs in city squares in terms of urban design and tourism attraction (Figure 3). 
Figure 3: Examples of shared photos from Sultanahmet Square with the source of Flickr
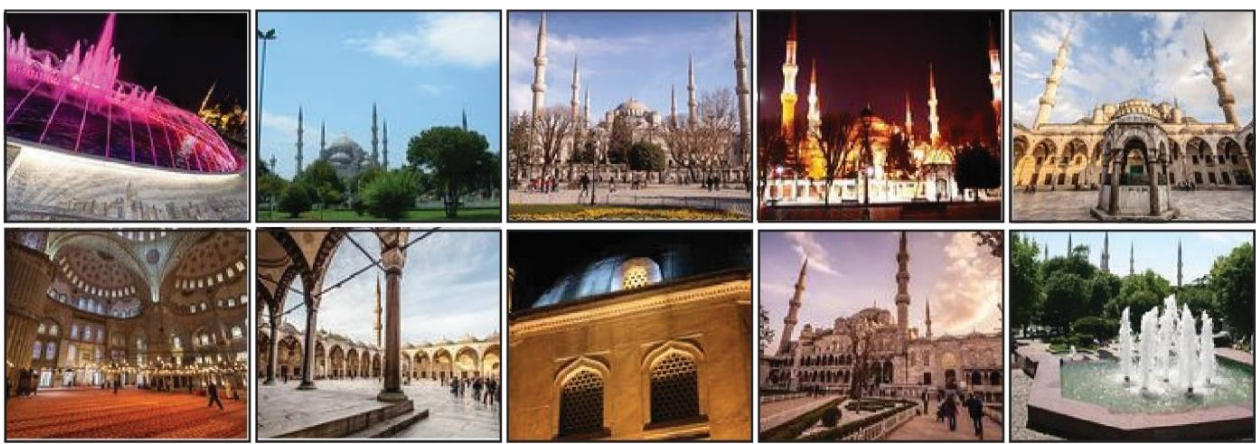

The date intervals on which Flickr data are shared appear to be the highest between the years of 2010 and 2018. The month with the most shares between these years is August. The most shared date is November 2012, with 654 photos. The photos shared were 54\% in Turkish, 37\% in English, and 9\% in other languages. It is observed that other languages consist of 20\% French, 16\% Spanish, 10\% German and Portuguese (Figure 4).

Figure 4: Temporal distribution of shared photos and language distribution of photo tags

Figure 4: Temporal distribution of shared photos and language distribution of photo tags
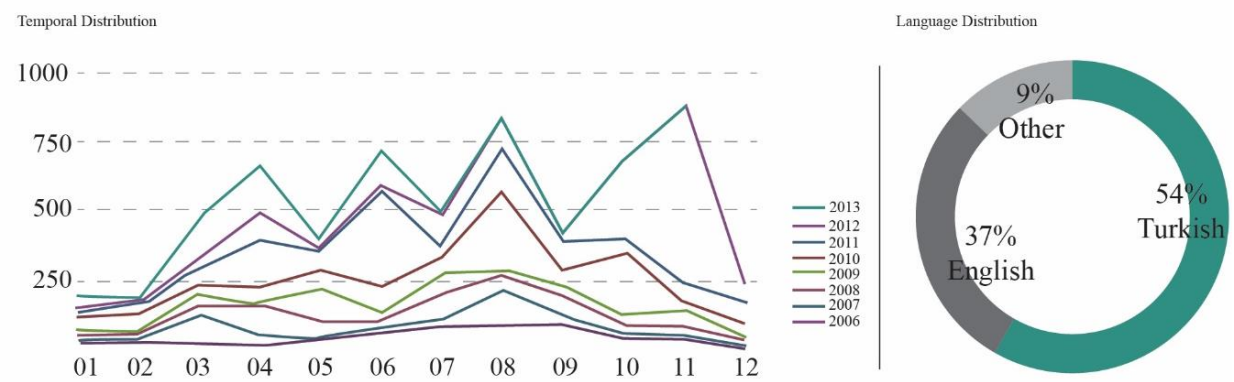

\section{User Evaluations of Urban Square}

Usage intensity analyses carried out in the study include the data of people using the Foursquare software. For this reason, people who are not users of the application are not represented. However, the squares have social media data that can be analyzed. A total of 18,459,291 check-in notifications are identified in the Istanbul city squares between August 2011 and August 2018. 860.313 of these notifications are located at Sultanahmet Square. 
The data received in the Foursquare "square" category include comments and dates for city squares. A total of 1000 reviews about Sultanahmet Square were obtained. Through the comments based on the user experience obtained from the social media data, the intensity of the users in the squares can be reached during the year. Thus, it was possible to assess it both spatially and temporally. Accordingly, the users of the square made most of the comments about the square in the summer months (Figure 5).

Figure 5: Seasonal distribution of user comments

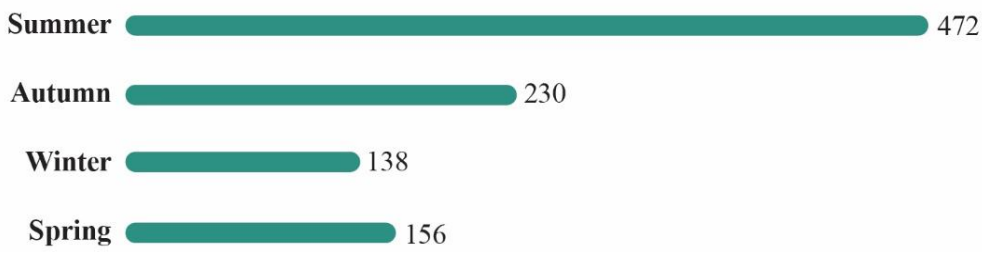

When the distribution of user comments by years is compared, it is seen that most comments were made between the years of 2013-2018. The preference may imply the decrease after 2015 for other photo-based social media such as Flickr, Instagram rather than Foursquare (Figure 6).

Figure 6: Distribution of user reviews by years

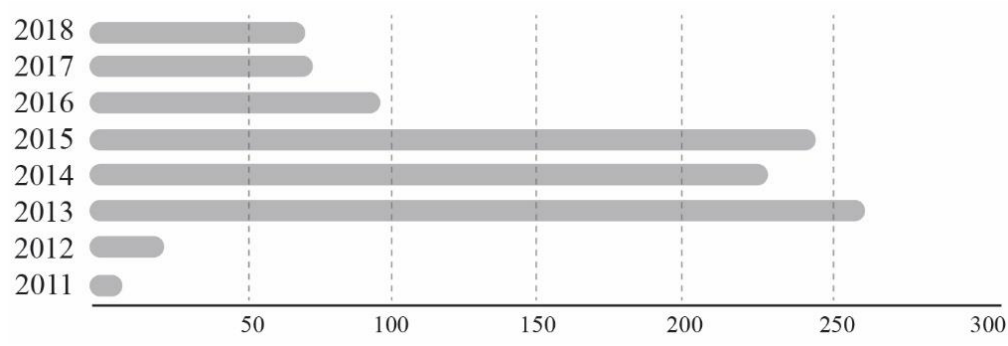

After the user comments of the urban squares were obtained with the API, the analyses were carried out in two different stages. Firstly, user comments were examined through text analysis methods, and the most used words in each city square were determined. According to the detailed text analysis, it is seen that the use of words "beautiful," "square," "history," "calm," "Sultanahmet," "tree," "wonderful," and "Ramadan" are higher in the Sultanahmet Square (Figure 7). 
Figure 7: Distribution of common words in Sultanahmet Square user comments beautiful square history calm sultanahmet tree wonderful ramadan

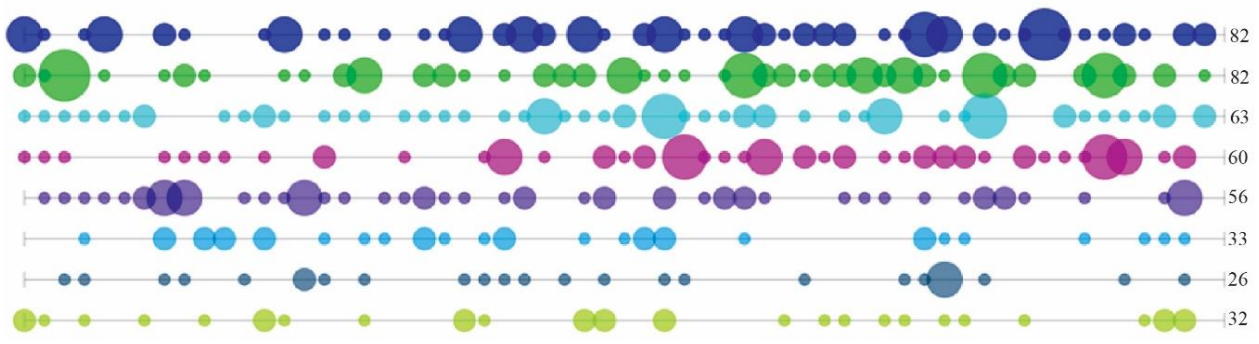

The historical structure of Sultanahmet Square, the high number of shopping places, the presence of trees in the square are described as positive features. It is concluded that the square, which is mostly commented in summer, makes the presence of trees and wind feel comfortable in summer. Besides, the square is described as comfortable in the evening. The increasing rate of the concrete floor due to the new square arrangement is considered to be negative.

The study was conducted to see if the data could contribute to the determination of touristic area identity characteristics. The study results indicate that social media data reflect the characteristic of the environment where the squares are located. It is concluded that historical monuments, public transportation alternatives around the square, land use type, ease of pedestrian movement within the square, and security are the essential factors in the choice of square usage.

As can be understood from both Foursquare reviews and Flickr photos, the architectural and historical structure of Sultanahmet Square constitutes an identity element for this square. According to the results obtained from visual and text analyses, it can be said that the information obtained from social media data reflects the usage characteristics and users' perception of the urban square.

\section{Conclusion}

The city's location-based social media networks and the integration of these data into tourism studies and urban design are gaining importance. This data can make it easy to identify popular areas, characteristics, and problems of the city. In the case of urban squares, this situation enables us to identify the factors that the users consider harmful in a short time and present the design problem. On the other hand, the integration of smart city systems and user-based data such as social media data is essential for developing the city based on user experiences. Data production is accelerating with increasing digital literacy. This data can be graphic-based or text-based. Either way, this 
database can provide more profound or new information, identify the place's characteristics, and initiate more research.

Social media data contribute to the studies in this regard to determine the problems and user preferences in the tourist area quickly. Also, it gives clues about the perception of tourists, the use of space, and the image of the area.

In this article, big data was used to reveal the visitors' views for the Sultanahmet region, an essential visiting area on Istanbul's historical peninsula. Visitors produce visual and written data about their travels using the Foursquare and Flickr applications. In this study, a methodology proposal is presented for the analysis of the data. The proposed method and field study examine the contribution of social media data made by the city squares to the city studies. This study aims to test whether the data can contribute to the development of the city and tourism relationship. According to this, social media data reflect the characteristics of the environment where the squares are located. It is concluded that the historical and architectural characteristics, the type of land use, and the ease of pedestrian movement within the square are the essential factors in the use of the touristic square.

This work contributes a potential way to bridge the research gap between urban design, tourism and urban perception. Local and dynamic characteristics perform leading functions in understanding the features of the public and touristic areas.

\section{References}

Alaei, A. R., Becken, S., and Stantic, B. (2019). Sentiment analysis in tourism: Capitalizing on big data. Journal of travel research, 58(2), 175-191.

Asakura, Y., and Iryo, T. (2007). Analysis of tourist behaviour based on the tracking data collected using a mobile communication instrument. Transportation research part A: Policy and practice, 41(7), 684-690.

Batty, M. (1990). Invisible cities. Environment and panning B: Planning and design, 17(2):127-130.

Batty, M. (1997). The computable city. International planning studies, 2(2):155-173.

Bawa-Cavia, A., (2011). Sensing the urban: using location-based social network data in urban analysis. In: The first workshop on pervasive urban applications (PURBA), 12-15 June, San Francisco, CA.

Borrego-Jaraba, F., Ruiz, I. L., and Gómez-Nieto, M. Á. (2011). A NFC-based pervasive solution for city touristic surfing. Personal and ubiquitous computing, 15(7), 731-742. 
Cerrone, D., (2015). A sense of place Turku urban research programmes. Research Report 1/2015. Available from: http://beta.turku.fi/sites/default/ files/atoms/files/

Chareyron, G., Da-Rugna, J., and Raimbault, T. (2014, October). Big data: A new challenge for tourism. In 2014 IEEE International conference on big data (big data) (pp. 5-7). IEEE.

Chua, A., Servillo, L., Marcheggiani, E., and Moere, A. V. (2016). Mapping cilento: using geotagged social media data to characterize tourist flows in Southern Italy. Tourism management, 57, 295-310.

Ciuccarelli, P., Lupi, G., and Simeone, L., 2014. Visualizing The data city. In: Social media as a source of knowledge for urban planning and management. Springer

Cools, D., McCallum, S. C., Rainham, D., Taylor, N., and Patterson, Z. (2021). Understanding Google location history as a tool for travel diary data acquisition. Transportation research record, 0361198120986169.

Cranshaw, J., Schwartz, R., Hong, J., and Sadeh, N. (2012, May). The Livehoods project: Utilizing social media to understand the dynamics of a city. In Sixth International AAAI conference on weblogs and social media, 58-65.

Del Vecchio, P., Mele, G., Ndou, V., and Secundo, G. (2018). Creating value from social big data: implications for smart tourism destinations. Information processing and management, 54(5), 847-860.

Egger, R. (2013). The impact of near field communication on tourism. Journal of hospitality and tourism technology. 4 (2), 119-133.

Elwood, S., Goodchild, M. F., and Sui, D. Z., (2012). Researching volunteered geographic information: spatial data, geographic research, and new social practice. Annals of the association of American geographers, 102(3), 571-590.

Frias-Martinez, V., Soto, V., Hohwald, H., and Frias-Martinez, E. (2012). Characterizing urban landscapes using geolocated tweets. In 2012, September, International conference on privacy, security, risk and trust and 2012 international conference on social computing, pp. 239-248 IEEE.

Fuchs, M., Höpken, W., and Lexhagen, M. (2014). Big data analytics for knowledge generation in tourism destinations-a case from Sweden. Journal of destination marketing and management, 3(4), 198-209.

García-Palomares, J. C., Gutiérrez, J., and Mínguez, C. (2015). Identification of tourist hot spots based on social networks: a comparative analysis of European metropolises using photo-sharing services and GIS. Applied geography, 63, 408-417. 
Girardin, F. et al., (2009). Quantifying urban attractiveness from the distribution and density of digital footprints. Int. j. spat. data infrastructures res. 4, 175-200.

Gretzel, U. (2011). Intelligent systems in tourism: a social science perspective. Annals of tourism research, 38(3), 757-779.

Hashem, I. A. T., Yaqoob, I., Anuar, N. B., Mokhtar, S., Gani, A., and Khan, S. U. (2015). The rise of "big data" on cloud computing: review and open research issues. Information systems, 47, 98-115.

Heikinheimo, V., Minin, E. D., Tenkanen, H., Hausmann, A., Erkkonen, J., \& Toivonen, T. (2017). User-generated geographic information for visitor monitoring in a national park: a comparison of social media data and visitor survey. ISPRS International journal of geo-information, 6(3), 85.

Hollenstein, L., and Purves, R. (2010). Exploring place through user-generated content: using Flickr tags to describe city cores. Journal of spatial information science, 2010(1), 21-48.

Irudeen, R., and Samaraweera, S. (2013, December). Big Data solution for Sri Lankan development: a case study from travel and tourism. In 2013 International conference on advances in ICT for emerging regions (ICTer) (pp. 207-216). IEEE.

Lazer, D., Brewer, D., Christakis, N., Fowler, J., \& King, G. (2009). Life in the network: The coming age of computational social. Science, 323(5915), 721-723.

Li, J., Xu, L., Tang, L., Wang, S., and Li, L. (2018). Big data in tourism research: A literature review. Tourism management, 68, 301-323.

Noulas, A., (2011). An empirical study of geographic user activity patterns in foursquare. In: Proceedings of the fifth international AAAI conference on weblogs and social media, 17-21 July, The AAAI Press, 570-573.

Nummi, P. (2017). Social media data analysis in urban e-planning. International journal of e-planning research (IJEPR), 6(4), 18-31.

Offenhuber, D., and Ratti, C., (2014). Decoding the city. In: Urbanism in the age of big data. Birkhäuser Verlag Gmbh

Senefonte, H., Frizzo, G., Delgado, M., Lüders, R., Silver, D., \& Silva, T. (2020). Regional influences on tourists mobility through the lens of social sensing. In International conference on social informatics (pp. 312-319). Springer.

Shao, H., Zhang, Y., and Li, W. (2017). Extraction and analysis of city's tourism districts based on social media data. Computers, environment and urban systems, 65, 66-78. 
Shem-Tov, I. B., and Bekhor, S. (2020). Extracting travel demand for emergency situations using location-based social network data. Transportation research procedia, 45, 111-118.

Silva, T.H., (2013). A comparison of Foursquare and Flickr to the study of city dynamics and urban social behavior. In: Proceedings of the $2 n d A C M$ SIGKDD international workshop on urban computing, 11-14 August, ACM.

WeAreSocial. (2020). Digital 2020 reports. Retrieved March 14, 2021, from https://wearesocial.com/blog/2020/01/digital-2020-3-8-billion-peopleuse-social-media.

Taras Agryzkov, Pablo Martí, Leandro Tortosa and José F. Vicent (2016): Measuring urban activities using foursquare data and network analysis: a case study of Murcia (Spain), International journal of geographical information science, DOI: 10.1080/13658816.2016.1188931

Thomee, B., Shamma, D. A., Friedland, G., Elizalde, B., Ni, K., Poland, D., and Li, L. J. (2015). The new data and new challenges in multimedia research. arXiv preprint arXiv:1503.01817, 1(8).

Yin, Z., Cao, L., Han, J., Luo, J., and Huang, T. (2011, April). Diversified trajectory pattern ranking in geotagged social media. In Proceedings of the 2011 SIAM International conference on data mining (pp. 980-991). Society for Industrial and Applied Mathematics.

Zhai, S., Xu, X., Yang, L., Zhou, M., Zhang, L., and Qiu, B. (2015). Mapping the popularity of urban restaurants using social media data. Applied geography, 63, 113-120.

Zhan, X. Ukkusuri, S. V. Zhu, F. (2014). Inferring urban land use using largescale social media check-in data, Networks, and spatial economics, 14(3-4), 647-667.

\section{Ethical approval}

This study is among the studies that do not require ethics committee approval due to not fall within the scope of research that requires one-to-one data collection from the participants and the data are obtained as secondary data.

\section{Contribution rate of researchers}

The authors contributed equally to the study.

\section{Conflict of interest}

There is no potential conflict of interest in this study. 